\title{
Research on The Mode of Talent Cultivation in Universities in Baoding in
}

\section{Beijing-Tianjin-Hebei Collaborative Development Background}

\author{
JING GUO ${ }^{1, a}$, LEI QI ${ }^{2, b}$ \\ ${ }^{1}$ College of Agronomy, Agricultural University of Hebei, Baoding, Hebei,China, 071000 \\ ${ }^{2}$ Hebei Cansina Engineering DesignN Co.,Ltd, Baoding, Hebei,China, 071000 \\ ${ }^{\text {b} E m a i l: ~ a p h e l i o n . q i @ h o t m a i l . c o m ~}$
}

Keywords: Beijing-Tianjin-Hebei Collaborative Development, The Mode of Talent Cultivation, Innovative Applied Talents

\begin{abstract}
According to the survey, we found that the cultivation of applied talents in universities in Baoding is not ideal, and there are many disadvantages in the field of college personnel training due to the outdated concept of education and education model. In this article, according to the requirements of Beijing-Tianjin-Hebei Collaborative Development, the author revolutionized the mode of talent cultivation in universities in Baoding, which is to achieve the universities in Baoding and the social market in line with the effective measures.
\end{abstract}

\section{Introduction}

To promote the comprehensive development of China's economy, China has been to give priority to economic development in key areas, and then drive economic development in other regions.Commonly known as "Beijing South Gate", Baoding city has a unique advantage in participating in Beijing-Tianjin-Hebei Collaborative Development. In <the Outline of Beijing-Tianjin-Hebei Collaborative Development Plan>Baoding was included in the central core functional areas, but also with Beijing, Tianjin, Langfang forming a triangular structure; and in <The Thirteen Five-Year Plan for National Economic and Social Development of Hebei Province> Baoding is positioned to innovation-driven development demonstration area of the Beijing-Tianjin-Hebei region, usher in a golden opportunity of development.

In economic geography, the labor force is one of the important location factors that affect the location of economic activity. For any country and region, high quality labor force is a scarce resource. Therefore, it is the most suitable area for the development of modern economic activities and the layout of the modern economic activities. The degree of intelligence and regional innovation is the key to whether a region has a modern economic activity. And the high school as a training place for high quality labor force can be cultivated and output a large number of high quality labor force.

\section{The Concept}

Beijing-Tianjin-Hebei Coordinated Development, the core is the coordinated development of Beijing-Tianjin-Hebei places as a whole, To ease the capital of non-core functions and to solve Beijing "big city disease" as the basic starting point, it adjusts and optimizes the layout of urban and spatial structure, building a modern transportation network, expands the capacity of the ecological environment of space, promotes industrial upgrading and transfer, promotes public service Sharing to speed up the process of market integration, creates a new modern metropolitan area, tries to form target direction and measures of the 
Beijing-Tianjin-Hebei region, complementary advantages, mutual benefit and win-win results of new pattern of coordinated development.

Innovative Applied Talents, It is based on the application, to balance the creativity, for local economic and social development of culture production, construction, management and service of the first line talent, basic education, government and social organizations at the grass-roots level business backbone, the backbone of the management and small and medium-sized enterprise entrepreneurial talent.

\section{Status and Problems of Talent Cultivation in Universities in Baoding}

Status. There are 17 colleges and universities in Baoding, including North China Electric Power University, Hebei University, Agricultural University of Hebei and so on, 180 thousand students in school. More than 140 including the central, provincial and all kinds of private scientific research institutions, all kinds of scientific and technical personnel more than 220000 people. Always been a "college town" reputation.

Baoding has formed a relatively complete talent training and knowledge dissemination system, the scale of higher education is increasing year by year. Has the following prominent features:

Higher Education Overall Strength Is Stronger. Baoding have both belong to the "211 Project", known as the "Whampoa Electricity Sector" North China Electric Power University, "Midwestern College Comprehensive Strength Promotion Project" Hebei University, national one of the earliest higher agricultural universities--Agricultural University Of Hebei; Also has a strong scientific research strength, including 1 national engineering research center, five national enterprise technology center, 21 provincial enterprise technology center; Three post-doctoral mobile stations, three postdoctoral workstation, 14 at or above the provincial level key laboratory, engineering and development institutions.

Education Resources Are Abundant and Industry Is Coordination. Baoding has a strong after-technological research strength, It has outstanding features of professional, rich resources of science and technology achievements, strong human resources competitive advantage and discipline; more science and engineering institutions, higher levels of talent training, the average size of the inter provincial graduate is greater than the national average. Effectively promote the development of Baoding industry and the upgrading of industrial structure, the structure of higher education can make the value of higher education resources.

Problems and Causes. A regional economic development needs a large number of scientific and technological achievements. However, universities and Baoding and the central core functional areas of cooperation in science and technology project is not satisfactory, the prominent problems mainly in the following four aspects:

Disciplinary Structure Is not Reasonable. In the aspect of talent supply, the irrational structure of Baoding higher education is not reasonable. The setting of Baoding college disciplinary structure and Baoding and the central core functional area of talent demand far, many universities opened the new discipline is often not enterprise need, Baoding and the central core functional area really need some high-tech talent can't satisfied, but go to the universities in the field of recruitment. Baoding focus on the development of automotive and spare parts, new energy, aerospace and new materials, energy saving and environmental protection and intelligent manufacturing and other advanced manufacturing. The author attached the research institutions in Agricultural University of Hebei . We can clearly see that the research institutions in universities and local development is not the case of integration.(Table 1)

The reason why the subject setting of universities in Baoding has these problems lies in: Firslyt, the education department and the school to the high technology industry structure adjustment and the evolution estimate is insufficient, the investigation and research is not fine. In recent years, Baoding has developed very fast, the industrial structure has changed a lot. Tens of thousands of students each year study in universities in Baoding, the traditional disciplines, many students in the school after graduation almost no counterparts; Secondly, universities lack the autonomy to set up and adjust the discipline; Thirdly, liberal arts training 
personnel investment cost is low, and the cost of science and engineering investment. So, in addition to liberal arts colleges, science and engineering universities have also started the liberal arts. The result leads the "accounting", "management", "foreign trade" full of talent market;

Table 1 The Research Institutions in Agricultural University of Hebei (Baoding Campus)

\begin{tabular}{|c|c|c|c|}
\hline $\begin{array}{l}\text { National Engineering Research } \\
\text { Center for Agricultural in } \\
\text { Northern Mountainous Areas }\end{array}$ & $\begin{array}{l}\text { Key Laboratory of Horticultural } \\
\text { Products Quality and Safety and } \\
\text { Variety Improvement of Ministry of } \\
\text { Agriculture }\end{array}$ & $\begin{array}{l}\text { Crop Germplasm } \\
\text { Resources Laboratory of } \\
\text { Hebei Province }\end{array}$ & $\begin{array}{l}\text { Crop Growth Control } \\
\text { Laboratory of Hebei } \\
\text { Province }\end{array}$ \\
\hline $\begin{array}{l}\text { Key Laboratory of Forest Tree } \\
\text { Germplasm Resources and } \\
\text { Forest Protection in Hebei } \\
\text { Province }\end{array}$ & $\begin{array}{l}\text { Cattle and Sheep Embryo Engineering } \\
\text { Technology Research Center in Hebei } \\
\text { Province }\end{array}$ & $\begin{array}{l}\text { National Soybean } \\
\text { Improvement } \quad \text { Center } \\
\text { Hebei Sub Center }\end{array}$ & $\begin{array}{l}\text { National Maize } \\
\text { Improvement Center } \\
\text { Hebei Sub Center }\end{array}$ \\
\hline $\begin{array}{l}\text { Research Center for Biological } \\
\text { Control of Crop Diseases and } \\
\text { Insect Pests in Hebei Province }\end{array}$ & $\begin{array}{l}\text { tain Agricultural Engineering } \\
\text { ology Research Center in Hebei } \\
\text { cce }\end{array}$ & $\begin{array}{l}\text { cal Inorganic } \\
\text { try Laboratory of } \\
\text { rovince }\end{array}$ & $\begin{array}{l}\text { National Fruit and } \\
\text { Vegetable Processing } \\
\text { Specialty Center }\end{array}$ \\
\hline $\begin{array}{l}\text { Light Metal Alloy Material } \\
\text { Engineering Technology } \\
\text { Research Center in Hebei } \\
\text { Province }\end{array}$ & $\begin{array}{l}\text { Agricultural products processing } \\
\text { engineering and Technology Research } \\
\text { Center in Hebei Province }\end{array}$ & $\begin{array}{l}\text { Rural Information } \\
\text { Engineering Technology } \\
\text { Research Center in } \\
\text { Hebei Province }\end{array}$ & 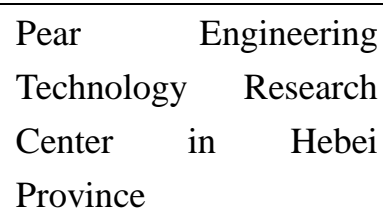 \\
\hline
\end{tabular}

The Educational Level Structure Does not Adapt. After investigation, we found that enterprises in Baoding mainly belong to the results of transformation of enterprises, high-tech R\&D institutions less. Therefore, a large number of undergraduate and tertiary levels of staff required in terms of academic levels, and graduate students do not occupy a large proportion of. However, in recent years, colleges and universities in Baoding enrollment plan found that college proportion accounted for less than $10 \%$. In addition, in the current college education, the specialty of the characteristics of more and more loss, the use of teaching materials, syllabus, teaching more and more closer to the undergraduate course. College education is not only the adjustment of quantity, but also the application and characteristics of it. In western developed countries, such as community colleges in the United States, the number of two year system students accounted for $60 \%$ of the total number of College students. The number of undergraduate level talent is too much will cause the waste of talents in some units of undergraduate students.(Table 2)

The Number of Students in Colleges and Universities in Baoding (2015) (Baoding Campus)

\begin{tabular}{|c|c|c|c|c|}
\hline \multirow{2}{*}{ Colleges and Universities } & \multicolumn{3}{|c|}{ The Number of Students } \\
\cline { 2 - 5 } & Junior College Students & Undergraduate & Graduate & Subtotal \\
\hline North China Electric Power University & & 20000 & 7000 & 27000 \\
\hline Hebei University & 10000 & 28000 & 5500 & 43500 \\
\hline Agricultural University Of Hebei & & 19737 & 2250 & 21987 \\
\hline National Police University of Criminal Justice & & 6336 & 150 & 6486 \\
\hline Hebei Finance University & 2927 & 8846 & 105 & 11878 \\
\hline $\begin{array}{c}\text { China University of Geosciences Great Wall } \\
\text { College }\end{array}$ & & 15000 & & 15000 \\
\hline Hebei Software Institute & 9000 & & & 9000 \\
\hline Baoding University & 6500 & 8000 & & 14500 \\
\hline Baoding Vocational and Technical College & 9900 & & & 9900 \\
\hline Baoding Electric Power Voc.\&Tech. College & 2000 & & & 2000 \\
\hline Hebei College of Science and Technology & & & & 9500 \\
\hline & 40327 & 105919 & 15005 & 170751 \\
\hline
\end{tabular}


The structure of school running is not fit. At present most of Baoding universities is a public, private Hebei Institute of technology although enrollment, but still anchored in Provincial Department of education, this single school structure was also in a certain extent, affected the vitality of the lack of competition. In addition, the running forms of a single structure but also in, not only ordinary colleges and universities in the school running forms consistent, TV University and University of Workers also emulate universities, and showed its own characteristics. In addition, it is not adaptable to the education and teaching management structure. In the current environment of market economy, on the one hand government called on Colleges and universities to serve the economic construction, establish take the initiative to adapt to the economic development mechanism, on the other hand, the management structure and largely regulated by the government plan, the needs of society must through the government intermediaries and information processing, to plan and executive orders issued to the school, so that colleges and universities is mainly in the face of the government, rather than directly oriented to the market, leading to lack of impetus for reform and active adaptation mechanism to form a truly. Therefore, in the development of higher education, it is not surprising that the phenomenon of the development of high tech Industrial Development Zone has been produced in universities.

\section{Established The Mode of Talent Cultivation in Universities in Baoding in Beijing-Tianjin-Hebei Collaborative Development Background}

Based on the analysis of Baoding urban development and the trend of talent demand, we put forward the following policy recommendations to the problems of Baoding and higher education:

Discipline Structure Should Be Adapted to The Development of Baoding. According to analysis of Baoding the direction of industrial development and talent demand trend, we recommended that universities in the setting up of the subjects should be around Baoding industrial structure, focus on the development of automobile and parts, new energy, aerospace and new materials, energy conservation, environmental protection and intelligent manufacturing of advanced manufacturing and professional disciplines. At the same time, the universities should strengthen the adaptability of the subject, widen the knowledge surface. In the past, universities of professional divided into meticulous, causing many students learn knowledge is too narrow, can not adapt to the needs of the development of high and new technology. At present, Baoding has begun to try to try to follow the discipline class or according to the college admissions. After freshman admission, the major study of the basic theory of wide caliber, to the high grade in accordance with the market demand for employment, the implementation of subject division, the choice of subject research direction, the implementation of professional education. Some universities also worked with the employing department, the implementation of pre-graduate distribution system. According to students' future work whereabouts, schools and employers jointly responsible for the implementation of targeted education and training, these are worth learn from successful practices.

The Reaching Content and Structure of Universities Should Be Consistent With The Development Direction of Baoding. Teaching content should highlight the cultivation of innovative talents. We suggested that the teaching content (curriculum structure) can be reflected the characteristics of innovation and application. First of all, there should be a large number of comprehensive science, the edge of science and horizontal science emerged, such as environmental science, life science, system science and so on. Secondly, natural science and social science should permeate and merge with each other. In addition, the trend is also reflected in the integration of science and technology to promote the growth point, a major breakthrough in theory and technology, and other aspects of the major inventions. More and more appear in the blank area between disciplines, disciplinary infiltration and metastasis, as the founder of cybernetics Willa said: "in the scientific development can get the biggest harvest field is had been established in various departments of neglected no man's land". The trend of comprehensive development of high technology challenges the traditional teaching content and structure of the universities. Therefore, in the professional setting, in addition to learn to emphasize 
discipline based class, we should also clearly stipulates, students must learn a number of doors and the adjacent disciplines or related discipline curriculum, actively encourage students to professional needs across disciplines and professional elective courses. In addition, in order to expand the knowledge of students, but also to open a number of cross disciplinary courses, introduce some cross disciplinary knowledge, develop students' horizons.

The Structure of Running Should Be Realized in Multilevel and Multiform. In the development of Baoding, the accelerated development and comprehensive characteristics of science and technology, as well as the interaction between science, technology and society and the extensive infiltration, all require the type structure of higher education to the comprehensive development. Baoding has 17 universities, Hebei University is the only comprehensive university in Baoding universities, it has the conditions for the establishment of interdisciplinary research institutions. Other universities such as University of North China Electric Power University, Agricultural University of Hebei, Hebei Finance University and other due to highlight the characteristics of professional, between colleges and universities established close ties, set up a variety of new disciplines and cross discipline is the leading professional discipline system or a group of subjects, to break the traditional specialty construction.

In the form of running a school, in addition to the focus on the development of ordinary higher education, relevant departments and universities can also run by University of the night, the self-study exam, professional managers and engineering and technical personnel of job training and training courses, the mode of running a school, broaden the ideas of running a university, through a variety of channels for social and economic development of available talent.

The Organization and Management Structure of Higher Education Should Embody The Openness and The Scientific. The management of students in Colleges and universities should adopt an open management mode. We suggest that through the reform of the management system, the higher education in different subjects, different subjects, different levels of students can utilize, cross department and cross disciplinary learning, promote the communication of college system. Currently, colleges and universities should emphatically in the on-the-job personnel through to rise only this, the master is to cultivate high-level talents, and in Colleges and universities with double majors, double degree, major minor system, elective system and other measures gradually open up the educational system, to create a relaxed environment for talented students. In order to adapt to the characteristics of high and New Technology Industrial Development Zone economic development, colleges and universities should also actively encourage students to start their own businesses, to provide a variety of conditions, For example, Tsinghua University the students implement flexible management, allowing some within a period of time in a field of special interest in students retain the school out entrepreneurship (including students).

Innovative Talent Introduction Mode, Expand Personnel Universities. Established talent that is the main resource for further development and expansion of universities. To update the introduction of talent way, is not only conducive to the expansion of university talent that is also conducive to the introduction of talent and retain talent, universities make recruitment and training of talent in Baoding become the main gathering land and carrier. We recommended a combination of universities and high-tech enterprise, founded by research institutes, post-doctoral research stations, Economic and Technological Development Zone, overseas students to start a round as the universities in Baoding and the introduction of more high-level personnel and shortage of professionals, grow Universities personnel, large-scale introduction and cultivation of talents.

\section{Conclusions}

Talent is an important support to promote the development of Baoding's economy, Universities in Baoding have made important contributions for the training and output of knowledge, skills and innovative applications of technology professionals. In this study, by the development of universities and Baoding as combing analysis, the author proposed reform measures on the coordinated development of the two, in order to promote the 
development of Baoding takeoff and Beijing-Tianjin-Hebei collaborative development. At the same time, the author also hoped to provide reference for local universities in adapting to the local development.

\section{Acknowledgements}

Foundation: Philosophy and Social Science Planning Project in Baoding City, No. 201201153; Research on The Mode of Talent Cultivation in Characteristic Special Universit in Beijing-Tianjin-Baoding Urban Integration Background, Agricultural University of Hebei

\section{References}

[1] Xiehui, Research on the training mode of science and technology talents based on the city of Beijing, Tianjin and Langfang [J].Career Horizon,2011(11).

[2] Liuqian, Study on the orientation and development of Baoding in the green economic circle around the capital [J].Guide to Business, ,2011(11).

[3] The Central Leading Group on Financial and Economic Affairs, The Outline of Beijing-Tianjin-Hebei Collaborative Development Plan [Z]. 2015-4-30.

[4] The People's Government of Hebei Province, The Thirteen Five-Year Plan for National Economic and Social Development of Hebei Province[Z]. 2016-4-18.

地址：保定河北农业大学东校区城建设计院 071000 祁雷收

电话: 13663322298 